\title{
MEMBANGUN KEINOVASIAN UMKM MELALUI PENINGKATAN PERAN ORIENTASI PASAR, KOMPETENSI SDM DAN ORGANISASI PEMBELAJARAN
}

\author{
Dewi Kurniawati \\ Jurusan Manajemen Fakultas Ekonomi dan Bisnis, Universitas Pancasila \\ dewi2706@gmail.com \\ Sri Widyastuti \\ Jurusan Manajemen Fakultas Ekonomi dan Bisnis, Universitas Pancasila \\ widyastuti.sri@univpancasila.ac.id \\ Laili Savitri Noor \\ Jurusan Manajemen Fakultas Ekonomi dan Bisnis, Universitas Pancasila \\ laili.savitri@gmail.com
}

Diterima 9 Agustus 2017, Disetujui 11 September 2017

Abstrak

Tujuan Penelitian ini adalah untuk memperoleh bukti empirik tentang pengaruh variabel orientasi pasar, kompetensi SDM, dan organisasi pembelajaran Pelaku Usaha UMKM di Kota Depok terhadap keinovasian UMKM. Penelitian ini dilakukan terhadap 100 orang responden Pelaku Usaha UMKM di Kota Depok. Penelitian ini menggunakan pendekatan kuantitatif dan pengolahan data menggunakan SPSS. Hasil penelitian ini menunjukkan adanya pengaruh yang signifikan dan orientasi pasar, kompetensi SDM, dan organisasi pembelajaran terhadap keinovasian UMKM. Ketiga variabel tersebut secara bersamasama mempengaruhi keinovasian UMKM di Kota Depok. Namun Kompetensi SDM dan Organisasi Pembelajaran lebih kuat dalam mempengaruhi pelaku usaha UMKM untuk dapat berinovasi dalam produknya dibandingkan dengan orientasi pasar.

Kata kunci: orientasi pasar, kompetensi SDM, organisasi pembelajaran, keinovasian, dan pelaku usaha UMKM

\section{Abstract}

The purpose of this study is to find empirical evidence about the effect of market orientation variables, human resource competencies, and learning organizations of SMEs business in Depok City on SMES innovation. This research was conducted on 100 respondents from SMEs business in Depok. This research uses quantitative approach and data processing using SPSS. The results of this study indicate a significant influence of market orientation, human resource competence, and learning organizations on the innovation of SMEs. These three variables simultaneously affect the innovation of SMEs in Depok City. The competence of Human Resources and Learning Organization are more influencing SMEs business to innovate their products compared to market orientation variable.

Keywords: market orientation, human resource competency, learning organization, innovation, business actor of SMEs 


\section{PENDAHULUAN}

\section{Latar Belakang}

Sektor Usaha Mikro Kecil dan Menengah (UMKM) di Indonesia sangat potensial untuk dikembangkan. UMKM merupakan soko guru perekonomian Indonesia, karena sektor ini terbukti memberikan kontribusi 57,12 persen terhadap Produk Domestik Bruto (PDB) tahun 2013. Sektor UMKM telah terbukti menopang perekonomian nasional, menyediakan lapangan kerja dan menekan angka kemiskinan serta meningkatkan kesejahteraan rakyat. Sektor ini sangat berpotensi dikembangkan, karena telah berkontribusi sebesar 574 triliun rupiah atau sebesar 7 persen dari produk domestik bruto, (Kemen Kop \& UKM, 2013). Informasi ini menggambarkan betapa besarnya peran UMKM bagi perekonomian Indonesia.

Menurut Mudradjad Kuncoro yang dikutip oleh Jauhari (2010), mengemukakan bahwa UMKM terbukti tahan terhadap tekanan krisis. Kondisi tersebut antara lain dikarenakan sektor ini, tidak memiliki hutang luar negeri, tidak banyak hutang ke perbankan karena mereka dianggap unbankable, menggunakan input lokal, dan berorientasi ekspor. Usaha pemberdayaan UMKM selalu di monitor dan di evaluasi perkembangannya berkaitan dengan Produk Domestik Bruto (PDB). Peningkatan jumlah UMKM menimbulkan persaingan usaha baik dengan sesama UMKM maupun dengan perusahaan besar.

Banyak permasalahan yang dihadapi oleh UMKM Indonesia, di antaranya rendahnya daya saing UMKM dipasar nasional maupun global. Kumorotomo (2008) yang dikutip dari Maryati (2012) mengungkapkan bahwa masih rendahnya daya saing UMKM tersebut karena masih besarnya masalah-masalah yang ada dalam pengembangan UMKM, seperti masalah pembiayaan, pemasaran, pengelolaan dan pengembangan Sumber Daya Manusia (SDM), dan efisiensi produksi serta keinovasian.

Organisasi UMKM diupayakan dapat unggul melalui keinovasian produk dan jasa yang didukung oleh kemampuan orientasi pasar, kompetensi SDM dan Orientasi Pembelajaran. Dari berbagai masalah tersebut diperlukan pengkajian secara mendalam tentang faktor-faktor apa saja yang paling dominan pengaruhnya terhadap peningkatan daya saing UMKM Indonesia.

Berdasarkan pemikiran di atas maka rumusan masalah penelitian ini adalah sejauh mana pengaruh orientasi pasar, kompetensi SDM, organisasi pembelajaran terhadap pembangunan keinovasian UMKM?

\section{Tujuan Penelitian}

Penelitian ini bertujuan untuk memperoleh bukti empirik tentang pengaruh orientasi pasar, kompetensi SDM, organisasi pembelajaran pelaku usaha UMKM terhadap keinovasian UMKM di Depok.

\section{KAJIAN TEORI}

\section{Orientasi Pasar}

Gray et al (2002) seperti dikutip Anshori (2011) berpendapat bahwa orientasi pasar dapat dilihat sebagai pelaksanaan konsep pemasaran yang kadang-kadang disebut orientasi pemasaran. Orientasi pasar didefinisikan sebagai perilaku organisasi yang mengidentifikasikan kebutuhan konsumen, perilaku kompetitor, menyebarkan informasi pasar ke seluruh organisasi, dan meresponnya dengan suatu koordinasi, perhitungan waktu, dan perhitungan keuntungan. Menurut Narver dan Slater (1990) yang dikutip dari Mardiyono (2015), menyatakan bahwa orientasi pasar terdiri dari 3 komponen perilaku yaitu orientasi pelanggan, orientasi pesaing, serta koordinasi interfungsional. Orientasi pelanggan dan orientasi pesaing termasuk semua aktivitasnya dilibatkan dalam memperoleh informasi tentang pembeli dan pesaing pada pasar yang dituju dan menyebarkan melalui bisnis. Koordinasi interfungsional didasarkan pada informasi pelanggan serta pesaing dan terdiri dari usaha bisnis yang terkoordinasi. Orientasi pelanggan diartikan sebagai pemahaman yang memadai tentang target beli pelanggan dengan tujuan agar dapat menciptakan nilai unggul bagi pembeli secara terus menerus.

\section{Kompetensi SDM}

Kompetensi SDM yang dibutuhkan untuk menghadapi tantangan baru dan jenis organisasi ditempat kerja, dapat diperoleh dengan pemahaman ciri-ciri yang kita cari dari orang-orang yang bekerja dalam organisasi-organisasi tersebut. UMKM membutuhkan kompetensi SDM yang handal untuk dapat membangun keinovasian sehingga menghasilkan keunggulan bersaing dengan UMKM lainnya. Kompetensi SDM UMKM terlihat dari individu-individu yang bekerja dan berkontribusi dalam UMKM tersebut seperti yang diungkapkan oleh Michael Armstrong (1998) dalam Kurniawan (2013) bahwa kompetensi individu adalah knowledge, skill dan kualitas individu untuk mencapai kesuksesan pekerjaannya. Dalam 
Widjajanti dkk (2014) kompetensi SDM termasuk dalam Human Capital.

Menurut Mathis dan Jackson (2001) seperti dikutip oleh Ardiana dkk (2016) mengilustrasikan bahwa kompetensi ada yang terlihat dan ada yang tersembunyi. Pengetahuan lebih terlihat, dapat dikenali oleh perusahaan untuk mencocokan orang dengan pekerjaan. Keterampilan walaupun sebagian dapat terlihat sebagian lagi kurang teridentifikasi. Akan tetapi kecakapan yang mungkin lebih berharga dapat meningkatkan kinerja. Leifer et al (2000) yang dikutip oleh Suliyanto (2010), menyatakan bahwa inovasi pada dasarnya bukan hanya terkait dengan pengembangan produk dan jasa, namun selain itu terkait pula pengembangan kompetensi perusahaan dimana di dalamnya terdapat SDM perusahaan. Kompetensi yang dibangun oleh perusahaan melalui SDM tersebut pada akhirnya akan menemukan keunggulan bersaing perusahaan. Maka UMKM membutuhkan peningkatan kompetensi SDM yang bekerja dan berkontribusi dalam UMKM untuk membangun keinovasian UMKM sehingga terwujud keunggulan bersaing.

\section{Oganisasi Pembelajaran}

George and Jones (2002) yang dikutip oleh Anshori (2011) mengemukakan bahwa pembelajaran merupakan perubahan permanen pada pengetahuan individu yang didapatkan dari hasil berbagai pelatihan maupun pengalaman. Ada tiga poin yang dapat dijabarkan dari definisi tersebut: (1) Dengan pembelajaran akan mewujudkan perubahan. Pengetahuan yang diperoleh oleh seorang individu merupakan hasil dari proses pembelajaran yang membutuhkan waktu tertentu; (2) Pengetahuan yang di dapat dari pembelajaran selalu diingat dan dipraktekkan dalam waktu yang lama; (3) Proses pembelajaran membutuhkan waktu tertentu untuk mendapatkan berbagai pelatihan, pengalaman, dan perilaku.

Menurut Gregory (2004 ) dalam Anshori (2011) mengungkapkan bahwa Pembelajaran itu sendiri berintikan suatu pengetahuan baru yang dapat mempengaruhi perilaku. Sedangkan Lee and Tsai (2005) dikutip dari Sugiyarti (2015) melihat orientasi pembelajaran sebagai suatu mekanisme yang mempengaruhi kemampuan perusahaan untuk menentang nilai-nilai lama terhadap pembelanjaran dan memfasilitasi teknik dan metodologi baru. Definisi ini secara langsung menjurus pada perubahan pemikiran organisasi.

\section{Inovasi}

Terdapat pengaruh orientasi pasar, orientasi kewirausahaan dan pembelajaran organisasi terhadap inovasi dan adanya inovasi UKM dengan keberanian nya mengambil risiko, secara proaktif menangkap peluang pasar dan mengembangkannyasecara otonom dapat merambah pasar melalui ekspor maupun waralaba, Sri Widyastuti, dkk (2017).

O’Regan dan Ghobadian (2005) dalam Sugiyarti (2015) melihat bahwa inovasi sebagai suatu ide baru yang dapat menciptakan nilai tambah bagi perusahaan. Han (1998) dikutip pada Anshori (2011) dalam penelitiannya mengemukakan bilamana suatu perusahaan menghadapi lingkungan bisnis yang mempunyai persaingan yang sangat tinggi, maka perusahaan tersebut harus mempunyai kemampuan untuk melakukan inovasi untuk memperbaiki kualitas.

Menurut Stata (1992) dikutip dalam Prakosa (2005) mengungkapkan bahwa agar dapat bersaing di pasar yang dinamis, perusahaan harus selalu terlibat dalam inovasi yang berkelanjutan. Kemampuan perusahaan dalam berinovasi ini akan meningkatkan perusahaan dalam menghasilkan produk-produk dan layanan bisnis yang berdaya saing tinggi. Wahyono (2002) dikutip dari Hapsari dkk (2014), menjelaskan bahwa inovasi yang berkelanjutan dalam suatu perusahaan merupakan kebutuhan dasar yang akan mengarah pada terciptanya keunggulan kompetitif. Seiring dengan perkembangan yang terjadi, pengertian inovasi juga mencakup penerapan gagasan atau proses yang baru. Inovasi juga merupakan mekanisme dalam beradaptasi dengan lingkungannya yang dinamis.

Lukas and Ferrel (2000) dalam Fatah (2013) menjelaskan adanya beberapa indicator dari inovasi produk , yaitu: 1) Perluasan Lini (linje extension) yaitu produk yang dihasilkan perusahaan tidak benar-benar baru tetapi relative baru untuk sebuah pasar; 2) Produk Baru (Me too-Product) yaitu produk baru bagi perusahaan tetapi relative tidak baru bagi pasar; 3) Produk Benar-Benar Baru (New-to-the-World) yaitu produk yang termasuk baru baik bagi perusahaan maupun pasar.

Dalam penelitian ini yang akan dijelaskan adalah hubungan orientasi pasar, kompetensi SDM, dan orientasi pembelajar terhadap keinovasian produk. Ketiga unsur tersebut (orientasi pasar, kompetensi SDM, dan orientasi pembelajar) mempengaruhi keinovasian produk. Semakin tinggi tingkat persaingan UMKM maka UMKM akan berusaha selalu membangun keinovasian sehingga menjadi keunggulan bersaing. 


\section{METODE}

Penelitian ini menggunakan pendekatan kuantitatif dengan pengujian hipotesis menggunakan statistik. Perhitungan dilakukan berdasarkan rumusrumus statistik dengan bantuan aplikasi Statistical Program for Social Science (SPSS) for Windows, kemudian dilakukan penafsiran terhadap angka-angka yang diperoleh sehingga akan diketahui sejauh mana hubungan dan pengaruh antar variabel yang diteliti.

Penelitian ini secara umum dilakukan untuk mengetahui pengaruh variabel Orientasi Pasar $\left(\mathrm{X}_{1}\right)$, variabel Kompetensi SDM $\left(\mathrm{X}_{2}\right)$, dan variabel Organisasi Pembelajaran $\left(\mathrm{X}_{3}\right)$ terhadap Keinovasian UMKM (Y). Model skematik penelitian yang akan dikembangkan dalam penelitian ini dapat digambarkan sebagai berikut:

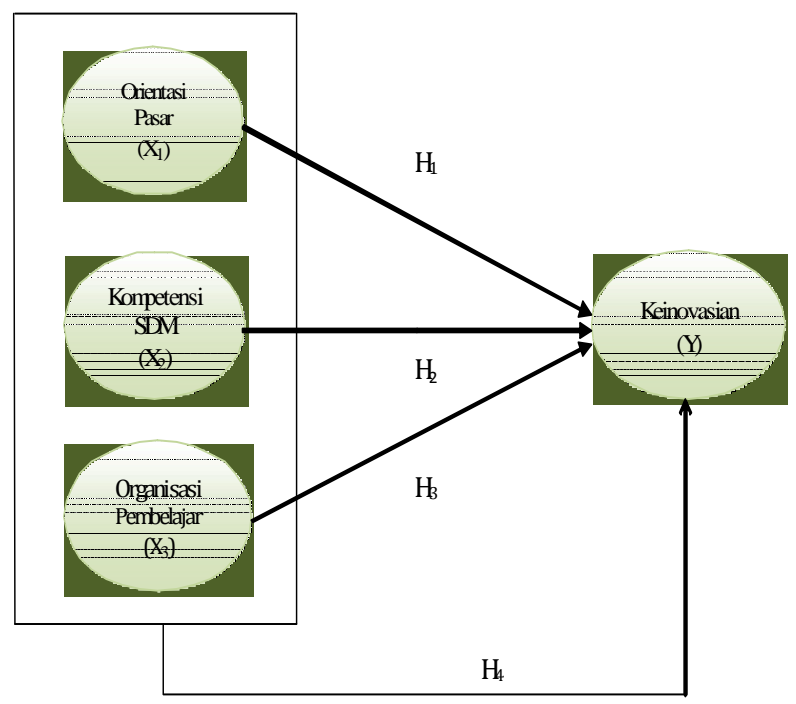

Gambar 1. Model hubungan Struktur $\mathrm{X}_{1}, \mathrm{X}_{2}$, dan $\mathrm{X}_{3}$ terhadap $\mathrm{Y}$

\section{Metode Pengumpulan Data}

Populasi adalah kumpulan menyeluruh dari suatu obyek yang merupakan perhatian penelitian. Sedangkan, sampel merupakan bagian dari jumlah dan karakteristik yang dimiliki populasi yang ingin diteliti. Dalam penelitian ini yang menjadi Populasi adalah Pelaku Usaha Mikro Kecil dan Menengah (UMKM) di Depok. Tehnik pengumpulan sampling yang digunakan dalam penelitian ini adalah probability sampling, yaitu tehnik penetapan sampel yang memberikan peluang yang sama kepada anggota populasi untuk dipilih menjadi anggota sampel.

\section{HASIL DAN PEMBAHASAN}

\section{Uji Reliabilitas dan Validitas Variabel}

Peneliti melakukan uji reliabilitas dan validitas pertanyaan-pertanyaan kuesioner masing-masing variabel orientasi pasar, kompetensi SDM, organisasi pembelajaran, dan keinovasian sebelum di analisis lebih lanjut. Hasil uji reliabilitas menunjukkan bahwa nilai cronbach's alpha variabel orientasi pasar sebesar 0,667, nilai cronbach's alpha variabel kompetensi SDM sebesar 0,789, nilai cronbach's alpha variabel organisasi pembelajaran sebesar 0,862, dan nilai cronbach's alpha variabel keinovasian sebesar 0,874.

Maka disimpulkan bahwa keempat variabel tersebut reliable karena nilai cronbach alpha masing-masing variabel $\geq 0,6$. Hasil uji validitas dari semua pertanyaan kuisioner untuk setiap variabel bernilai lebih besar 0,3 sehingga dapat disimpulkan bahwa semua pertanyaan kuesioner keempat variabel valid karena nilai $\mathrm{R}$ (Corrected item- Total Corelation) $\geq 0,3$.

\section{Profil Responden}

Peneliti melakukan penetapan sampel berjumlah yaitu 100 responden. Karakteristik data responden yaitu pelaku usaha UMKM di Depok sebanyak 58\% responden adalah laki-laki dan $42 \%$ perempuan. Hal ini menunjukkan bahwa pelaku usaha UMKM di Depok adalah lebih banyak laki-laki dari pada perempuan. Pelaku usaha UMKM di Depok ratarata berusia 25 sampai 44 tahun karena usia tersebut merupakan usia produktif untuk dapat bekerja. Dalam hal pendidikan, pelaku usaha UMKM di Depok sebagian besar (69\%) berpendidikan SLTA. Penghasilan pelaku usaha UMKM di Depok mempunyai penghasilan antara $<2$ juta sampai dengan 4,9 juta. Dan pelaku usaha UMKM di Depok sebagian besar (50\%) berpengalaman usaha selama 2- 4 tahun.

\section{Hasil Pengujian Hipotesis}

Hasil pengujian hipotesi dilakukan setelah dilakukan uji reliabilitas dan validitas masing-masing variabel. Setelah mendapatkan varibel-variabel yang reliable dan valid dilakukan uji selanjutnya dengan menggunakan SPSS. Pada penelitian ini menghasilkan persamaan regresi berganda yaitu $\mathrm{Y}$ $=1,281+0,039 X_{1}+0,518 X_{2}+0,777 X_{3}$ dapat dilihat pada tabel 1, dengan nilai kostanta (a) bernilai 1,281. Angka tersebut berarti bahwa apabila besaran $\mathrm{X}_{1}$, $X_{2}$, dan $X_{3}$ sama dengan nol, maka besaran nilai konstanta sebesar 1,281. Besaran $b_{1}$ adalah 0,039, artinya apabila variabel $\mathrm{X}_{1}$ (Orientasi Pasar) naik satu satuan maka besarnya $\mathrm{Y}$ (Keinovasian) meningkat sebesar 0,039. Nilai b2 yaitu 0,518, artinya apabila variabel $\mathrm{X}_{2}$ (Kompetensi SDM) 
naik satu satuan maka Y (Keinovasian) meningkat sebesar 0,518 , dan nilai $b_{3}$ sebesar 0,777 artinya apabila variabel $\mathrm{X}_{3}$ (Organisasi Pembelajaran) naik satuan maka $\mathrm{Y}$ (Keinovasian) meningkat sebesar 0,777 .

Tabel 1. Hasil Analisis Regresi Berganda

\begin{tabular}{ll|c|c|c|cc}
\hline \multirow{2}{*}{ Model } & \multicolumn{2}{c|}{ Unstandardized Coefficients } & Sig. & \multicolumn{2}{c}{ F } \\
\cline { 2 - 6 } & B & Std. Error & & \multicolumn{2}{c}{} \\
\hline \multirow{2}{*}{1 Constant) } & 1.281 & 3.274 & .696 & & 76.122 \\
Orientasi Pasar & & & & Sig. & .000 \\
& Kompetensi SDM & .039 & .125 & .755 & & \\
Organisasi Pembelajaran & .518 & .138 & .000 & & \\
\hline
\end{tabular}

Sumber: hasil proses SPSS (data 2015)

Penelitian ini juga untuk menunjukkan uji Linieritas terhadap persamaan regresi berganda di atas dengan rumusan hipotesis sebagai berikut :

$\mathbf{H}_{\mathbf{0}}$ :Tidak ada hubungan linier antara orientasi pasar, kompetensi SDM, dan organisasi pembelajaran dengan keinovasian.

$\mathbf{H}_{\mathbf{1}}$ :Ada hubungan linier antara orientasi pasar, kompetensi SDM, dan organisasi pembelajaran dengan keinovasian.

Berdasarkan hasil analisis bahwa terdapat hubungan yang positif dan siginikan antara orientasi pasar, kompetensi SDM, dan organisasi pembelajaran terhadap keinovasian, terlihat pada tabel 1 dimana bahwa nilai F hitung sebesar 76,122 sedangkan untuk F tabel adalah 4,74 (tabel distribusi F dengan taraf signifikansi 5\%, karena Fhit $>$ Ftabel maka tolak $\mathrm{H}_{\mathrm{O}}$ sehingga disimpulkan bahwa ada hubungan linier antara variabel orientasi pasar $\left(\mathrm{X}_{1}\right)$, kompetensi SDM $\left(\mathrm{X}_{2}\right)$, dan organisasi pembelajaran $\left(\mathrm{X}_{3}\right)$ dengan keinovasian $(\mathrm{Y})$. Hasil ini juga dapat dilihat pada nilai Sig. sebesar 0,000 yang artinya nilai Signifikasi lebih kecil dari taraf signifikasi 5\%. Dengan demikian dapat dikatakan bahwa terdapat hubungan kausal yang signifikan antara orientasi pasar, kompetensi SDM dan organisasi pembelajaran terhadap keinovasian. Sehingga pelaku usaha UMKM di Depok dapat membangun keinovasian dengan meningkatkan orientasi pasar, kompetensi SDM, dan organisasi pembelajaran seperti dalam penelitian Pinaringasnih (2015) bahwa ada hubungan positif dan signifikan antara orientasi pasar dengan keinovasian dan juga dalam penelitian Widjajanti dkk (2014) yang menyatakan bahwa ada hubungan positif signifikan antara human capital dalam hal ini kompetensi SDM dengan keinovasian dan juga ada hubungan positif signifikan antara organisasi pembelajaran dan keinovasian.
Penelitian ini juga mendapatkan hasil bahwa pengaruh orientasi pasar dengan keinovasian sebesar 0,365 sehingga dapat disimpulkan bahwa hubungan antara variabel orientasi pasar dengan keinovasian rendah berbeda dalam penelitian Pinaringasnih (2015) menyatakan bahwa orientasi pasar mempunyai hubungan yang kuat dan sangat mempengaruhi keinovasian. Sedangkan pengaruh kompetensi SDM dengan keinovasian sebesar 0,654 sehingga dapat disimpulkan bahwa hubungan antara kompetensi SDM dengan keinovasian kuat seperti dalam penelitian Widjajanti dkk (2014) yang menyatakan bahwa human capital dalam hal ini kompetensi SDM sangat mempengaruhi keinovasian. Pengaruh organisasi pembelajaran terhadap keinovasian sebesar 0,809 sehingga dapat dibahas bahwa hubungan antara variabel organisasi pembelajaran dengan keinovasian sangat kuat juga seperti dalam penelitian Widjajanti dkk (2014) bahwa organisasi pembelajaran sangat memengaruhi keinovasian. Berdasarkan analisis ternyata variabel orientasi pasar kurang memengaruhi keinovasian UMKM di Depok. Sehingga pelaku usaha UMKM di Depok perlu melakukan perhatian dan fokus pada pesaing, pelanggan, dan koordinasi interfungsional seluruh UMKM.

Hasil pengolahan data dengan bantuan SPSSS yang terlihat pada Tabel 1 menggunakan taraf signifikansi 5\% menunjukkan bahwa variabel Orientasi Pasar $\left(\mathrm{X}_{1}\right)$ mempunyai nilai signifikansi sebesar 0,755. Jika dibandingkan dengan $\alpha$ (taraf signifikansi) 5\% maka Sig. = 0,755 lebih besar dari taraf signifikansi sehingga dapat dikatakan bahwa variabel Orientasi Pasar $\left(\mathrm{X}_{1}\right)$ tidak berpengaruh secara statistik pada Keinovasian (Y). Orientasi pasar tidak berpengaruh terhadap keinovasian UMKM di Kota Depok karena pelaku usaha kurang memfokuskan pada pesaing, pelanggan, dan 
koordinasi interfungsional UMKM seperti dalam teori Narver dan Slater (1990). Variabel kompetens SDM $\left(\mathrm{X}_{2}\right)$ mempunyai nilai signifikan sebesar 0,000 . Jika dibandingkan dengan $\alpha$ (taraf signifikansi) $5 \%$ maka Sig. $=0,000$ lebih kecil dari taraf signifikansi sehingga dapat disimpulkan bahwa variabel kompetens SDM berpengaruh secara statistik pada Keinovasian (Y). Kompetensi SDM berpengaruh dalam keinovasian UMKM di Kota Depok karena ketrampilan, pengetahuan, dan kecakapan individu-individu yang berada dalam organisasi sesuai dengan tujuan UMKM dan keinginan masyarakat Depok seperti dalam teori Mathis dan Jackson (2001) dan Lukas and Ferrel (2000). Variabel Organisasi Pembelajaran $\left(\mathrm{X}_{3}\right)$ mempunyai nilai signifikansi sebesar 0,000. Jika dibandingkan dengan $\alpha$ (taraf signifikansi) $5 \%$ maka Sig. $=0,000$ lebih kecil dari taraf signifikansi sehingga dapat disimpulkan bahwa Variabel Organisasi Pembelajaran $\left(\mathrm{X}_{3}\right)$ berpengaruh secara statistik pada Keinovasian (Y). Organisasi pembelajaran juga sangat berpengaruh terhadap keinovasian UMKM di Depok karena pelaku usaha sudah melakukan pelatihan-pelatihan bagi dirinya maupun karyawannya untuk meningkatkan inovasi UMKM nya seperti dalam teori George and Jones (2002). Sehingga dapat disimpulkan bahwa variabel yang mempunyai pengaruh yang signifikan secara statistik terhadap keinovasian adalah variabel kompetensi SDM dan organisasi pembelajaran. Koefisien determinasi persamaan regresi berganda sebesar 0,695 terlihat pada Tabel 2 pada kolom adjusted $R$ square maka dapat disimpulkan bahwa variabel orientasi pasar, variabel kompetensi SDM, dan variabel organisasi pembelajaran bersama-sama berkontribusi memengaruhi keinovasian sebesar 69,5 \% sedangkan sisanya 31,5\% dipengaruhi oleh variabel lain diluar variabel yang diteliti. Sehingga dapat disimpulkan bahwa orientasi pasar, kompetensi SDM, dan organisasi pembelajaran yang dilakukan oleh pelaku usaha UMKM mempengaruhi secara bersama-sama terhadap keinovasian UMKM di Kota Depok. Maka di Kota Depok dapat dibangun keinovasian produk UMKM dengan meningkatkan orientasi pasar, kompetensi SDM, dan organisasi pembelajaran pelaku usaha UMKM.

Tabel 2. Hasil Analisis Determinasi

\begin{tabular}{cccccc}
\hline Model & $\mathrm{R}$ & $\begin{array}{c}\mathrm{R} \\
\text { Square }\end{array}$ & $\begin{array}{c}\text { Adjusted R } \\
\text { Square }\end{array}$ & $\begin{array}{c}\text { Std. Error of } \\
\text { the Estimate }\end{array}$ & Durbin-Watson \\
\hline 1 & $.839^{\mathrm{a}}$ & .704 & .695 & 3.044 & 2.183 \\
\hline
\end{tabular}

Sumber: hasil proses SPSS (data 2015)

\section{SIMPULAN DAN SARAN}

Dari analisis dan pengujian yang telah diuraikan maka dapat disimpulkan bahwa orientasi pasar, kompetensi SDM, dan organisasi pembelajaran mempunyai pengaruh signifikan terhadap keinovasian UMKM di Depok. Keinovasian UMKM di Depok dapat di bangun dengan meningkatkan orientasi pasar, kompetensi SDM, dan Organisasi pembelajaran. Ketiga varibel tersebut secara bersama-sama mampu menjelaskan keinovasian UMKM sebesar 69,5 \%.

Organisasi pembelajaran memberikan pengaruh yang sangat kuat terhadap keinovasian yakni sebesar 0,809. Hal ini membuktikan bahwa dengan pelatihanpelatihan yang selama ini dilakukan dan pengalaman yang sudah di dapat oleh pelaku usaha dapat mengubah perilaku dan membuka wawasan baru bagi pelaku usaha UMKM di Depok. Dengan terus meningkatkan organisasi pembelajaran maka akan lebih menguntungkan bagi pelaku usaha sehingga membuat UMKM di Depok dapat berkembang pesat.

Sedangkan Kompetensi SDM juga berpengaruh kuat terhadap keinovasian UMKM yakni sebesar
0,654. Ini dapat dijelaskan karena kompetensi SDM merupakan modal bagi UMKM untuk mencapai kesuksesan. Keinovasian dapat dilakukan oleh UMKM di Depok jika ketrampilan, pengetahuan, dan kecakapan individu-individu yang berada dalam organisasi sesuai dengan tujuan UMKM dan keinginan masyarakat Depok. Pelaku usaha UMKM di Depok perlu meningkatkan terus ketrampilanketrampilan, pengetahuan, dan kecakapan dirinya dan karyawannya sehingga dapat selalu membangun keinovasian UMKM sehingga masyarakat selalu menyukai dan membeli produknya.

Namun orientasi pasar kurang memengaruhi keinovasian UMKM di Depok, yakni hanya sebesar 0,365. Hal ini terjadi karena pelaku usaha UMKM kurang memfokuskan pada pesaing, pelanggan, dan koordinasi interfungsional UMKM. Orientasi pasar dapat membangun keinovasian jika pelaku usaha UMKM dapat meningkatkan pengetahuan tentang keinovasian pesaing, keinginan pelanggan, dan selalu mempunyai hubungan dengan organisasi lain atau UMKM lainnya sebagai penambah informasi untuk dapat membangun keinovasian.

Dari hasil penelitian ditemukan bahwa rata-rata 
responden sudah membangun keinovasian, rata-rata melalui kompetensi SDM dan organisasi pembelajaran. Secara empirik melalui penelitian lebih lanjut dapat menguatkan data empiris tersebut. Namun sebagaimana penelitian-penelitian yang sudah ada peluang-peluang dalam membangun keinovasian yang belum tercakup dalam lingkup penelitian ini. Masih perlu dilakukan penelitian lanjutan untuk mendapatkan variabel-variabel lain yang mampu membangun keinovasian lebih baik melalui upaya strategis di luar variabel penelitian umum yang ada saat ini.

\section{DAFTAR PUSTAKA}

Anshori, Muhammad Yusak, 2011, Pengaruh Orientasi Pasar, Intellectual Capital, dan Orientasi Pembelajaran terhadap Inovasi: Studi Kasus Pada Industri Hotel di Jawa Timur, Jurnal Manajemen Bisnis, Volume 3 No. 3. 317-329.

Fatah, Ahmad Vian Abdul , 2013, Pengaruh Inovasi Produk dan Orientasi Pasar terhadap Keunggulan Bersaing: Survey terhadap UKM Batik Deden Tasikmalaya, Jurnal Fakultas Ekonomi UniKom Bandung.

Hapsari, Gusti Ruzayda Eka, Djumilah Hadiwidjojo, dan Armanu Thoyib, 2014, Pengaruh Pembelajaran Organisasional, Orientasi Pasar, dan Inovasi Organisasi terhadap Keunggulan Bersaing (Studi pada PT. Bank Rakyat Indonesia (Persero) Tbk Cabang Malang Raya), Jurnal Aplikasi Manajemen Universitas Brawijaya, Vol 12 No.1

I.D.K.R. Ardiana, I.A Brahmyanti, Subaedi, 2016, "Kompetensi SDM UKM dan Pengaruhnya Terhadap Kinerja UKM di Surabaya”, Jurnal Manajemen dan Kewirausahaan, Vol. 12 No.1, halaman 45

Jauhari, Jaidan, 2010, Upaya Pengembangan Usaha Kecil dan Menengah (UKM) dengan Memanfaatkan ECommerce, Jurnal Sistem Informasi (JSI), Vol 2 No 1, Hal 159-168

Kurniawan, Agung Widhi, 2013, Strategi Pengelolaan Bisnis: Menciptakan Keunggulan Bersaing Melalui Kompetensi Sumber Daya Manusia, Universitas Negeri Makassar, Makassar.

Lee, Tien-Shang \& Tsai, Hsin-Ju , 2005, The Effect of Business Operation Mode on Market Orientation, Learning Orientation and Innovativeness, Industrial Management \& Data System, Vol 105, No. 3, 325-378

Leifer, R. Et al 2000. Redical Innovation: Hor Matur Companies Can Outsmart Upstarts, Harvard Business School Press, 2000 dalam Wolpert, J.D.2002, Breaking Out of the Innovation Box. Harvard Business Review, August 2002, p.78
Mardiyono, Aris, 2015, Pengaruh Orientasi Pasar,Pembelajaran Organisasi Terhadap keunggulan Bersaing Dalam Meningkatkan kinerja Pemasaran, Jurnal Ilmiah UNTAG semarang, Vol 11 SSN 2302-495X

Maryati, Wiwik, 2012, Peran perguruan Tinggi Dalam Pemberdayaan Entrepreneurship Untuk Mengembangkan Wirausahawan kecil Menghadapi Persaingan Global, Jurnal Prosiding Seminar Competitive Advantage UNIPDU Jombang, Vol 1 No 2

O'regon, Nicholas \& Ghobadian, A, 2005, Innovation in SMEs: The Impact of Strategic Orientation and Environtmental Perceptions, International Journal of Productivity and Performance Management, Vol 54, No. 2, 81-97

Pinaringasnih, Sri Andini, 2015, Pengaruh Orientasi Pasar terhadap Inovasi Produk Usaha Kecil dan Menengah Sektor Kerajinan Tangan (Studi Kasus Pada UKM Peserta UKM Galeri SMESCO), Jurnal Ilmiah Universitas Bakrie, Volume 3, No. 02.

Prakosa, Bagas, 2005, Pengaruh Orientasi Pasar, Inovasi, dan Organisasi Pembelajaran Terhadap Kinerja Perusahaan Untuk Mencapai Keunggulan Bersaing (Studi Empiris Pada Industri Manufaktur Di Semarang), Jurnal Studi Manajemen dan Organisasi, Vol 2 No 1

Sugiyarti, Gita, 2015, Membangun Keunggulan Bersaing melalui Orientasi Pembelajaran, Orientasi Pasar, dan Inovasi Produk, Jurnal Ilmiah UNTAG Semarang.

Suliyanto, 2010, Peranan Pembelajaran Organisasional Dalam Mengkonversikan Orientasi Pasar Menjadi Kinerja Pemasaran:Proses dan Agenda penelitian, Jurnal EKOBIS, Vol 11 No 1, hal 446-457

Wahyono, 2002, Orientasi Pasar dan Inovasi:Pengaruhnya terhadap Kinerja Pemasaran, Jurnal Sains Pemasaran Indonesia, Vol 1, No. 1, Mei

Widjajanti, Kesi, Widodo, 2014, Pengembangan Inovas Organisasi, Sharing Knowledge, dan Pembelajaran Organisasional, Jurnal Universitas Islam Sultan Agung Semarang, Vol 15, No 1, Juli.

Widyastuti, S, Qosasi, A, Noor, L. S. and Kurniawati, D. (2017). Enhancing, The Competitive Advantage of SMEs through Innovation. The Role of Market and Entrepreneurship Orientation, Learning Organization. International Journal of Economic Research. ISSN 0972-9380. Vol 14 No. 20, Pp 203-221 